\title{
Whitefly Control Strategies against Tomato Leaf Curl New Delhi Virus in Greenhouse Zucchini
}

\author{
Estefanía Rodríguez *, Ma Mar Téllez and Dirk Janssen (ii) \\ IFAPA, La Mojonera Centre, 04745 Almería, Spain \\ * Correspondence: mestefania.rodriguez@juntadeandalucia.es
}

Received: 27 June 2019; Accepted: 23 July 2019; Published: 26 July 2019

\begin{abstract}
Background: Tomato leaf curl New Delhi virus (ToLCNDV), transmitted by tobacco whitefly (Bemisia tabaci Gennadius) (Hemiptera: Aleyrodidae), is of major concern in the cultivation of zucchini. The threat of this virus motivates reliance on chemical vector control but European consumers' demands for vegetables grown free of pesticides provides an important incentive for alternative pest management; (2) Methods: Different whitefly management strategies and ToLCNDV incidences were surveyed in commercial zucchini greenhouses in south-east Spain. In an experimental greenhouse, three different whitefly control strategies, biological, chemical, and integrated (IPM), were evaluated in a replicated trial to determine the most effective strategy for virus suppression (3) Results: Whitefly was present in all commercial zucchini crops surveyed, whereas fewer crops had Amblyseius swirskii or other natural enemies. During three consecutive years, pest management was increasingly based on chemical treatments. Yet, ToLCNDV was widespread in zucchini greenhouses. Experimental results showed that the order of best strategy for virus suppressing was integrated management $(73 \%)>$ biological control $(58 \%)>$ chemical control (44\%); and (4) Conclusions: IPM was the best strategy for virus suppression. The results can assist in the design of appropriate control strategies for chemical pesticide reduction and decision-making in pest management.
\end{abstract}

Keywords: augmentative biological control; Cucurbita pepo; parasitoids; predators; protected horticulture; begomovirus

\section{Introduction}

The largest horticultural greenhouse producing area in Europe is located in south-east (SE) Spain (31,000 ha). The whitefly, Bemisia tabaci (Gennadius) (Hemiptera: Aleyrodidae), is one of the most serious pests found in protected horticulture because of its broad host range, high reproductive rate, and short life cycle [1]. The most frequent damage they cause is due to the hundreds of plant viruses (> 350 species) they are able to transmit, which include members of the genera Begomovirus (Geminiviridae), Crinivirus (Closteroviridae), Ipomovirus (Potyviridae), Carlavirus (Betaflexiviridae), and Torradovirus (Secoviridae) [2]. Most economically important viruses are begomoviruses, which have increased their distribution and importance worldwide [3], and are responsible for significant yield losses in Spanish horticulture [4,5].

Traditionally, chemical control has been the dominant strategy in B. tabaci management. Consequently, the pest has developed resistance and cross-resistance to a wide range of insecticides in the field. Mediterranean species (MED, also commonly known as biotype $\mathrm{Q}$ ) is the most predominant and devastating biotype across horticultural crops in SE Spain $[5,6]$. Moreover, biotype $Q$ shows greater resistance to insecticides compared with the widespread biotype $B[7,8]$. This likely explains the displacement of biotype $B$ by biotype $Q$ in many Mediterranean countries $[9,10]$. Adequate climatic as well as agronomic conditions in SE Spain, e.g., year-round greenhouse crop production, favor the presence of high populations of $B$. tabaci and, consequently, the introduction of new begomoviruses [5]. 
In fact, Spanish horticulture greenhouses have been recently invaded by the bipartite begomovirus, tomato leaf curl New Delhi virus (ToLCNDV), which infects solanaceous and cucurbitaceous crops, but which is especially aggressive in zucchini crops. Since its introduction in 2013, it has caused considerable economic losses in Spain [11,12].

There is a rising demand by European consumers for reduced pesticide use in horticulture due to health reasons and the need to protect the environment [13]. Integrated pest management (IPM) is an interdisciplinary approach for control of agricultural pest populations that is regulated in the European Union Member States (Directive 2009/128/EC). Augmentative biological control is an important component of IPM programs in protected horticulture. The predatory mite Amblyseius swirskii Athias-Henriot (Acari: Phytoseiidae) is particularly useful against the whitefly in sweet pepper and cucumber [14-19]. Semifield tests showed that zucchini plants harboring A. swirskii have lower ToLCNDV incidence with less virus spreading than plants without $A$. swirskii [20]. Moreover, preinstallation of $A$. swirskii on zucchini seedlings supplemented with pollen as food resource allows building up of large populations of predators before the pest arrives $[19,20]$. Little is known about the current phytosanitary balance and virus-spread in commercial zucchini greenhouses from SE Spain, or which of the whitefly reducing strategies (chemical, biological or IPM) is optimal for virus suppression. In order to avoid pesticide overuse, the first objective of this study was to investigate the recent evolution of $B$. tabaci in commercial zucchini crops under conventional (chemical) and integrated management, and the most recent incidence of ToLCNDV. The second objective was to compare the effectiveness of a biological (particularly, the preinstallation of the predatory mite A. swirskii), chemical (conventional management), and integrated strategy in an experimental greenhouse to determine the most successful measure for ToLCNDV suppression in zucchini.

\section{Materials and Methods}

\subsection{Commercial Zucchini Crop Monitoring}

During the three consecutive campaigns of 2015-2016, 2016-2017, and 2017-2018, zucchini crops grown in 44 commercial greenhouses in the province of Almeria in SE Spain $\left(36^{\circ} 45^{\prime} 06^{\prime \prime} \mathrm{N}, 2^{\circ} 41^{\prime} 04^{\prime \prime} \mathrm{W}\right)$ were screened for the presence of $B$. tabaci and A. swirskii (Figure 1). Naturally occurring predators and parasitoids of B. tabaci such as Nesidiocoris tenuis (Reuter) (Hemiptera: Miridae) and Eretmocerus mundus (Hymenoptera: Aphelinidae) were also evaluated. The type of whitefly management, either chemical (conventional) or integrated, was annotated for each of the 13, 22, and 23 zucchini crops that were screened during the respective crop campaigns. During the month of December 2017, 35 other zucchini greenhouses, located in the region of Nijar (East from the capital city of Almería) were monitored for the presence of ToLCNDV symptoms that typically include curling and yellowing in young leaves [21]. The data were compiled by the Andalusian Ministry of Agriculture, Livestock, Fisheries and Sustainable Development, within the Warning and Information Plant Protection Network of the Andalusia Government (Red de Alerta e Información Fitosanitaria; RAIF in Spanish) [22] and retrieved by Antonio De Pablo Gómez-Bastero (Tragsa-SEPI, Seville, Spain) on 20 March 2019. 


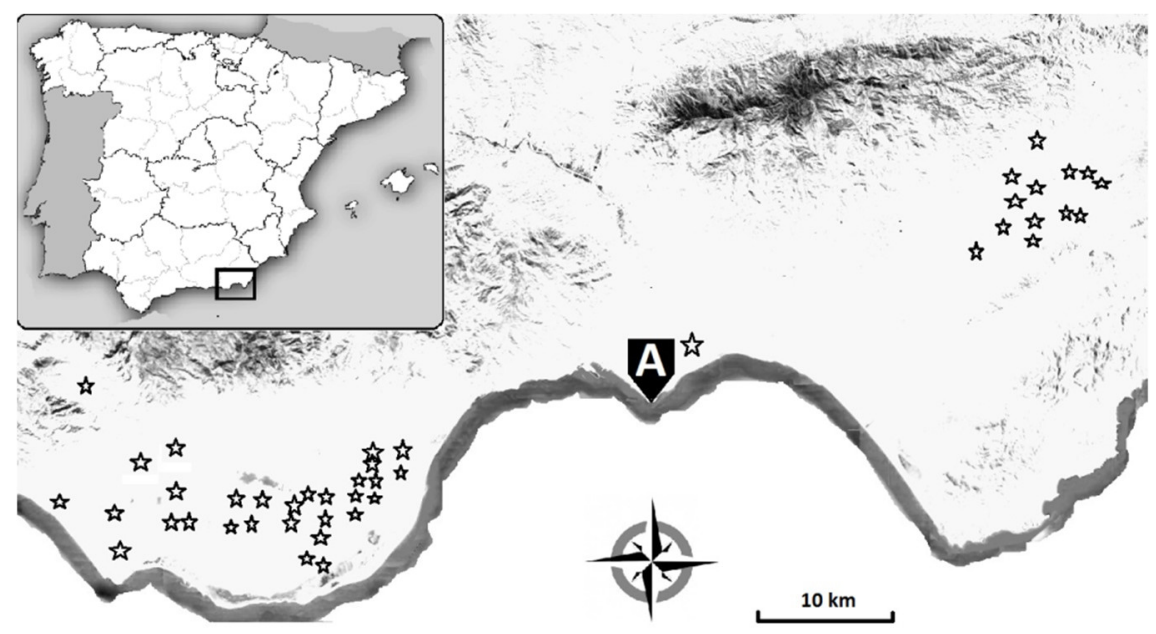

Figure 1. Location of 44 greenhouses surveyed for monitoring whitefly-control strategies during 2015-2018. The survey of tomato leaf curl New Delhi virus (ToLCNDV) was carried out in another 35 zucchini greenhouses in 2017 (not shown). (A) Almería city.

\subsection{General Experimental Procedures}

The experiments were conducted in a greenhouse complex from May to July 2017 at the Centre IFAPA La Mojonera, Almería, Spain. The complex spanned $1500 \mathrm{~m}^{2}$ and consisted of one surrounding corridor and eight research compartments of approximately $100 \mathrm{~m}^{2}$, oriented east-west. Each compartment consisted of five rows with 15 plants each. Four hundred and fifty three-week-old seedlings (three true leaves-stage) of zucchini plants (Cucurbita pepo L.) cv. Victoria (HM. Clause, Spain) were transplanted into perlite grow bags with a volume of 100 liters at a density of three plants per bag. Two of these compartments (replicates) were randomly assigned to one whitefly control strategy (treatment). The three whitefly control strategies were as follows (1) "CB treatment" consisted of preinstallation of the predatory mite A. swirskii in zucchini seedlings; (2) "Chemical treatment" consisted of application of conventional pesticides; and (3) "IPM treatment" consisted of preinstallation of $A$. swirskii in zucchini seedlings in combination with application of pesticides compatible with the predatory mites (Table 1). Each treatment was separated from the other treatments by an empty compartment which served as a "buffer zone". For the biological control treatment, predatory mites were supplied by Agrobio S.L. (La Mojonera, Almería, Spain) and provided in commercial paper sachets of 250 individuals supplemented with storage mites (all stages) mixed with bran. Predators were transferred to seedlings within $24 \mathrm{~h}$ of receipt, three days prior to transplanting, and released at the rate of $\sim 55$ individuals per plant [20]. For the chemical treatment, two applications of conventional pesticides per week were sprayed to run-off using a pressurized sprayer. The pesticides applied under this strategy were those used commonly by growers (Table 1). For the IPM treatment, the predatory mites were applied as described above and in combination with a single application of biorational pesticides per week (Table 1). One day after transplanting, all crops were inoculated with twenty-five viruliferous whiteflies released at a height of $1.5 \mathrm{~m}$ from the soil into the center of each compartment to simulate a natural whitefly invasion and spread. The ToLCNDV-viruliferous whiteflies were taken from colonies maintained on zucchini plants (cv. Victoria) in insect-proof cages under controlled rearing conditions at $25 \pm 3^{\circ} \mathrm{C}$ and with a photoperiod of $16: 8 \mathrm{hlight} / \mathrm{dark}$. The population was periodically tested for ToLCNDV to confirm the presence of virus. The biotype of the B. tabaci populations, was determined by partial mitochondrial cytochrome oxidase I gene sequencing as described and was found to belong to the Mediterranean cryptic species subclade Q1, following the methodology described by Gueguen et al. [23]. 
Table 1. Biological, chemical, and integrated treatment schedule applied in the experimental greenhouse compartments.

\begin{tabular}{cccc}
\hline Dates & Biological & Chemical 1 $^{\text {1 }}$ & Integrated 1 $^{\text {1 }}$ \\
\hline $\begin{array}{c}\text { 3 days before } \\
\text { transplanting }\end{array}$ & $\begin{array}{c}\text { Amblysius swirskii } \\
\text { (55 individuals/plant) }\end{array}$ & $\begin{array}{c}\text { Amblyseius swirskii } \\
\text { (55 individuals/plant) }\end{array}$ \\
\hline Weeks 1,5 & $\begin{array}{c}\text { acetamiprid } \\
\text { phosphoric soap }\end{array}$ & pymetrozine \\
\hline Weeks 2,6 & $\begin{array}{c}\text { pymetrozine } \\
\text { phosphoric soap }\end{array}$ & phosphoric soap \\
\hline Weeks 3,7 & $\begin{array}{c}\text { acetamiprid } \\
\text { phosphoric soap } \\
\text { Week 4 }\end{array}$ & $\begin{array}{c}\text { spirotetramat } \\
+ \text { azadirachtin }\end{array}$ & phosphoric soap \\
\hline
\end{tabular}

${ }^{1}$ pesticides were applied against whitefly at the recommended doses.

\subsection{Monitoring B. tabaci and ToLCNDV Symptom Evolution in Experimental Greenhouse Compartments}

Pest pressure outdoors was monitored weekly during the experiment (seven weeks) by counting captures of adult whiteflies on twelve $25 \times 10 \mathrm{~cm}$ yellow sticky traps (two traps/compartment oriented north-south) (Agrobio S.L. La Mojonera, Almería, Spain) placed inside the greenhouse corridor at 1, $60 \mathrm{~cm}$ of the soil. Observations within greenhouse compartments were done every week on the next day after pesticide applications over 7 weeks. For each treatment and repetition, three zucchini leaves per plant were gently turned to reveal the leaf underside, and the numbers of $B$. tabaci adults were recorded ( $n=450$ leaves/treatment). Expression of ToLCNDV symptoms was monitored as described above during six consecutive weeks on all the zucchini plants and in every greenhouse compartment.

\subsection{Data Analysis}

The numbers of $B$. tabaci adults were expressed as insect-day accumulated values (IDA). This index proposed by Ruppel [24], was applied to evaluate the total pest impact at a given period of time. Population trends were compared by adjusting the IDA to different sigmoid functions using the Table curve 2D v 5.01 statistical software (Systat Software, Inc., San Diego, CA, USA). IDA end values were analyzed by the generalized linear model. The models were fitted by maximum likelihood estimation with the GenLin procedure with gamma errors and the log link function using the IBM SPSS version 25.0 statistical software package [25]. The significance of the model was assessed by an Omnibus test to test whether the explained variance in a data set was significantly greater than the unexplained overall variance. For the regression effect specified in the model, a Wald statistic was conducted, which is based on the linearly independent pairwise comparisons among the estimated marginal means [26]. Then, the mean values were compared pairwise at $p=0.05$. Analysis of ToLCNDV expression was done calculating the proportions of plants that expressed symptoms of the 15 plants in each of ten rows per treatment. These proportions were used to calculate the area under disease progress curve (AUDPC) following Campbell and Madden [27]. The means and standard deviations of AUDPC values per treatment were calculated and differences between means were evaluated using the $t$-test (double sided probability, $p<0.05$ ).

\section{Results}

\subsection{Phytosanitary Balance, Pest Management, and ToLCNDV Incidence in Commercial Zucchini Crops}

During the three consecutive crop seasons between 2015 and 2018, B. tabaci whiteflies were present in almost all monitored zucchini crops grown in commercial greenhouses form the province of Almeria. During the first and the third campaign, all of the greenhouses had this whitefly species on more than 
$5 \%$ of plants. Initially, none of the greenhouses had natural enemies E. mundus and N. tenuis, but a few of them had N. tenuis by the campaign of 2017-2018. Predatory mite A. swirskii, however, was found in about $69 \%$ of screened greenhouses during 2015-2016, but this ratio dropped to 36 and 35\% of greenhouses during the two following years (Table 2).

Table 2. Number (\% of total) of zucchini crops with whitefly (Bemisia tabaci), commercial release of Amblyseius swirskii and naturally occurring parasitoid and predator (Eretmocerus mundus and Nesidiocoris tenuis) on more than $5 \%$ of plants.

\begin{tabular}{cccccc}
\hline Campaign & Greenhouses $(\boldsymbol{n})$ & B. tabaci & A. swirskii & E. mundus & N. tenuis \\
\hline $2015-2016$ & 13 & $12(92.3 \%)$ & $9(69.2 \%)$ & $0(0.0 \%)$ & $0(0.0 \%)$ \\
$2016-2017$ & 22 & $19(86.4 \%)$ & $8(36.4 \%)$ & $0(0.0 \%)$ & $3(13.6 \%)$ \\
$2017-2018$ & 23 & $22(95.6 \%)$ & $8(34.8 \%)$ & $0(0.0 \%)$ & $2(8.7 \%)$ \\
\hline
\end{tabular}

During the campaign of 2015-2016, IPM was predominantly used in the monitored zucchini crops $(69 \%)$, whereas the remaining greenhouses used chemical pest control. However, during the two following years, the numbers of greenhouses with chemical pest control increased to over $60 \%$ of the greenhouses, whereas less than $40 \%$ used IPM (Table 3).

Table 3. Number (\% of total) of zucchini crops with chemical or integrated pest control of B. tabaci.

\begin{tabular}{cccc}
\hline \multirow{2}{*}{ Campaign } & \multirow{2}{*}{ Greenhouses $(\boldsymbol{n})$} & \multicolumn{2}{c}{ Pest Management $(\boldsymbol{n} \mathbf{( \% )})$} \\
\cline { 3 - 4 } & & Chemical & Integrated \\
\hline $2015-2016$ & 13 & $4(30.8 \%)$ & $9(69.2 \%)$ \\
\hline $2016-2017$ & 22 & $14(63.6 \%)$ & $8(36.4 \%)$ \\
\hline $2017-2018$ & 23 & $14(60.9 \%)$ & $9(39.1 \%)$ \\
\hline
\end{tabular}

Visual inspection for symptoms of ToLCNDV indicated the presence of the virus in zucchini crops in 34 of 35 monitored greenhouses during the fall of 2017. More than $5 \%$ and $20 \%$ of plants had symptoms, in 34 and 28 greenhouses, respectively (Figure 2).

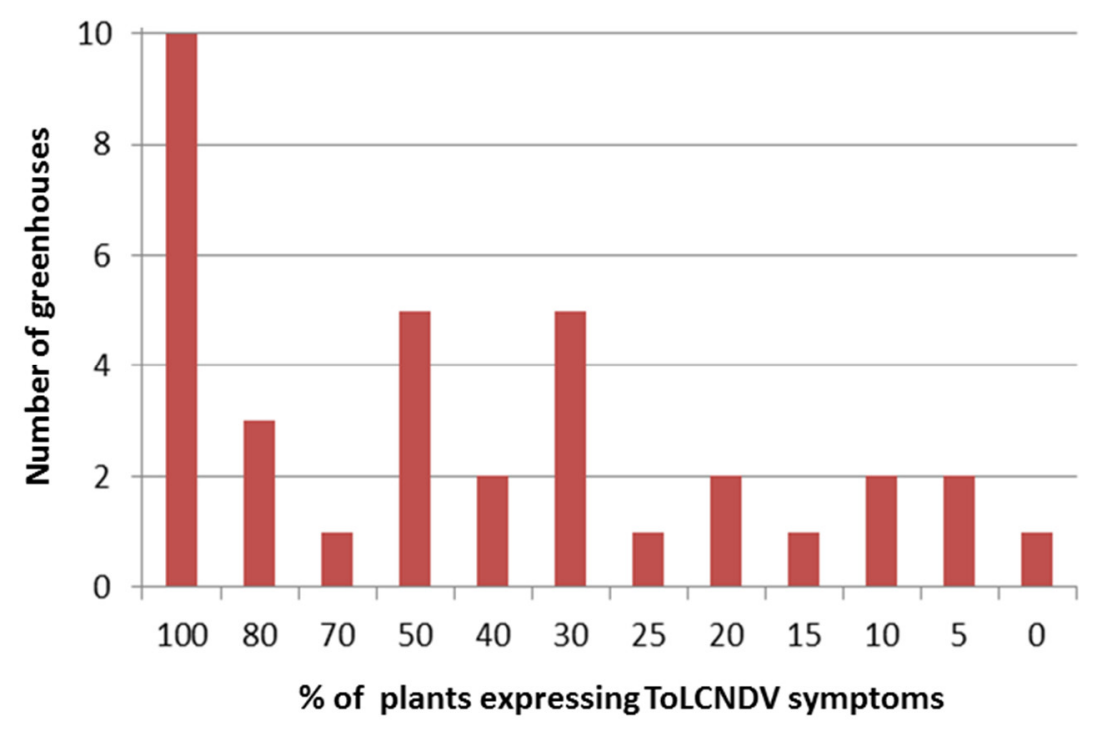

Figure 2. Greenhouse frequency distribution of ToLCNDV-symptomatic plants. 


\subsection{Whitefly and ToLCNDV Evolution in Experimental Greenhouse Compartments}

\subsubsection{Whitefly}

Temporal dynamics of whitefly population outdoors were similar in all treatments (biological, integrated, and chemical) during the seven weeks of monitoring, as indicated by number of whitefly adults accumulated on yellow sticky traps (Figure 3). Cumulative mean numbers increased intensely from week 5 , rising from a mean value of about 500 whiteflies on week 1 to about 3200 on week 7 (Figure 3). However, the final number of accumulated whitefly adults in IPM treatment exceeded 3700 individuals. Thus, pest-pressure effect on zucchini plants was very similar on biological and chemical compartments, but was higher on IPM compartments.

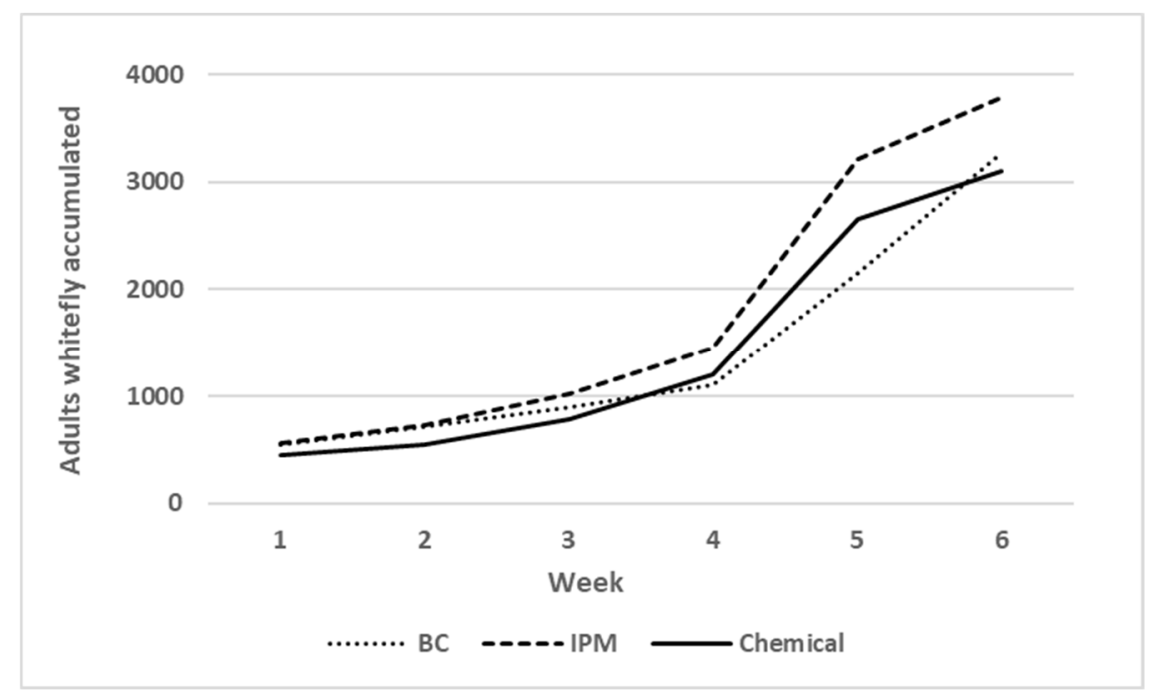

Figure 3. Accumulated average number of adult whitefly per yellow sticky trap outdoors of the experimental greenhouse compartments.

With respect to the dynamics of whitefly populations indoors, the factor (treatment) of the model had a significant effect on the value of IDA at the end of the trial (Omnibus test, likelihood ratio $\chi^{2}=52.454, d . f .=2 ; p<0.001$ ) (Table 4). The biological control strategy showed the lowest whitefly population at the end of the crop, followed by the integrated and the chemical strategy $(p<0.001)$ (Table 4). The lowest pest population (not exceeding 12.27 whiteflies per leaf) was observed under the biological treatment in week 7 , followed by that under the integrated treatment with values not exceeding 24.46 whiteflies per leaf. Conversely, higher numbers of IDA of B. tabaci were observed under the chemical strategy, which induced the higher pest population at the end of the crop, with 41.97 whiteflies per leaf in week 7.

Table 4. IDA (insect-day accumulated) values for B. tabaci at the end of the zucchini cultivation (week 7) under three different whitefly control strategies. Means within a column followed by the same letter are not significantly different a $p=0.05$; Wald Chi-Squared Test $=43.21$, $\mathrm{gl}=2, p<0.0001$.

\begin{tabular}{cccc}
\hline Strategy & Mean & SE & 95\% Confidence Interval (Wald) \\
\hline Biological & $12.27 \mathrm{a}$ & 1.43 & $9.75-15.44$ \\
Integrated & $24.46 \mathrm{~b}$ & 2.86 & $19.45-30.78$ \\
Chemical & $41.97 \mathrm{c}$ & 4.92 & $33.36-52.80$ \\
\hline
\end{tabular}

The accumulated numbers of $B$. tabaci adults under the biological $(\mathrm{F}=165 ;$ d.f. $=2 ; p<0.0001$; $\left.\mathrm{R}^{2}=0.99\right)$ and integrated $\left(\mathrm{F}=898.3\right.$, d.f. $\left.=2, p<0.0005 ; \mathrm{R}^{2}=0.99\right)$ strategy fitted a logistic function fairly well. Quantitative data analysis of $B$. tabaci indicated that both biological and integrated treatments 
were important in reducing and controlling the virus vector at the end of the crop. By contrast, the evolution of $B$. tabaci accumulated numbers under chemical treatment was well described by an exponential function ( $\left.F=653.9, d . f .=1, p<0.0000 ; R^{2}=0.88\right)$ (Figure 4). In this case, estimated numbers of adults of $B$. tabaci constantly increased along the time, particularly since week 3 , indicating that whitefly was not being controlled successfully by exclusively using a chemical control.

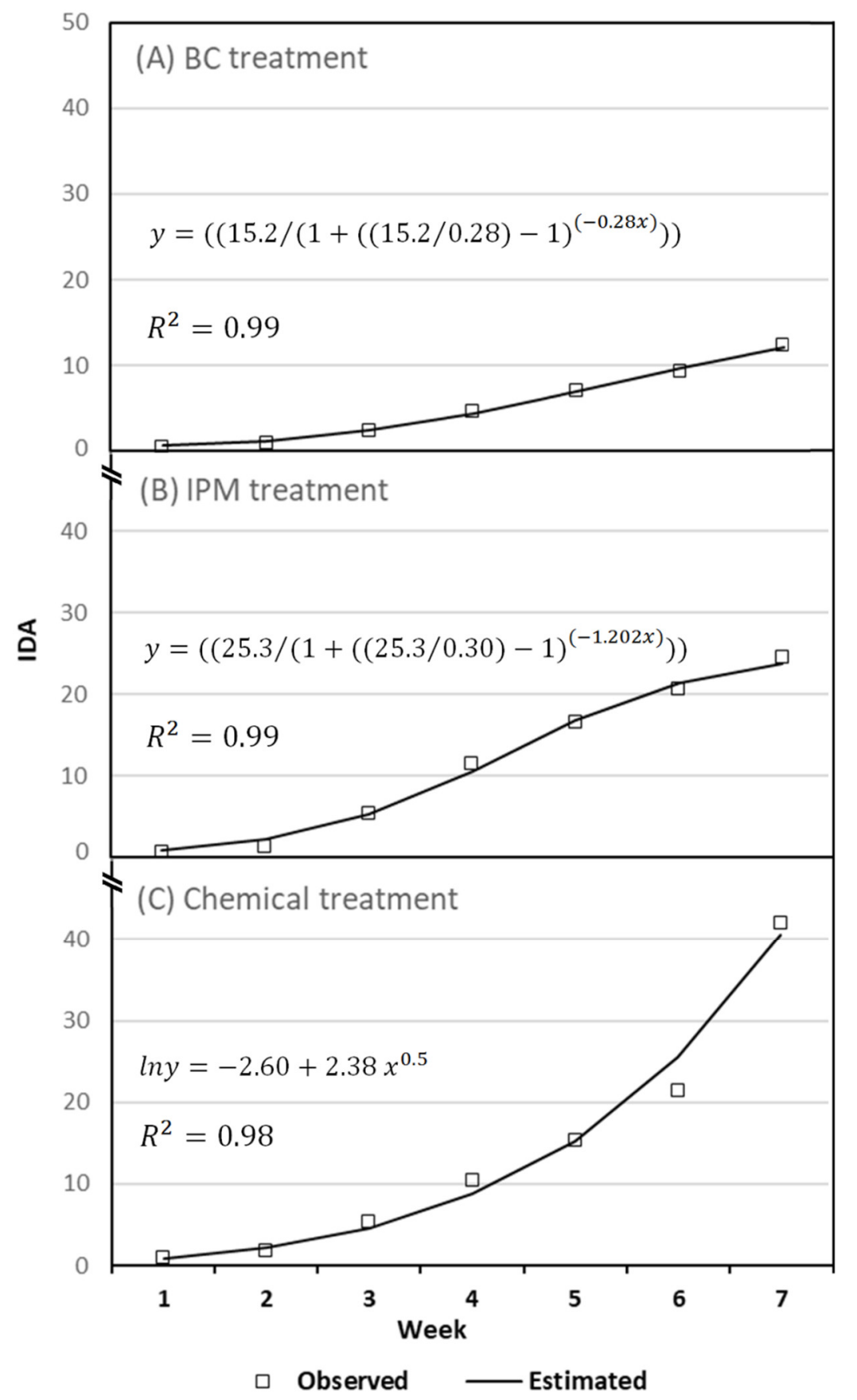

Figure 4. Mean insect-day accumulated values (IDA) of adults of B. tabaci under biological (A), integrated (B), and chemical (C) control strategies from experimental data $(\square)$ and predicted values (-) by nonlinear functions. The cumulative experimental data under biological (A) and integrated (B) strategies fitted to a logistic equation and that under chemical strategy $(\mathrm{C})$, to an exponential equation. 


\subsubsection{ToLCNDV Symptom Evolution}

Between weeks 1 and 2 and following the release of viruliferous whiteflies, increasing numbers of zucchini plants expressed the typical symptoms of ToLCNDV. Already during the first few weeks of the trial, zucchini crops under the integrated strategy showed fewer plants expressing symptoms when compared with plants under biological or chemical control. Plants under the later strategy expressed more symptoms when compared with biological control after four weeks of infection (Figure 5). The maximum proportions of symptomatic plants under the different control strategies were $0.56,0.42$, and 0.27 , under chemical, biological, and integrated whitefly management, respectively. The means and standard deviations of calculated AUDPC values were $10.1 \pm 4.8,8.4 \pm 4.6$, and $5.04 \pm 4.7$ for ToLCNDV under, respectively, chemical, biological, and integrated whitefly management. AUDPC means of symptomatic plants under chemical and integrated strategies were significantly different (Table 5).

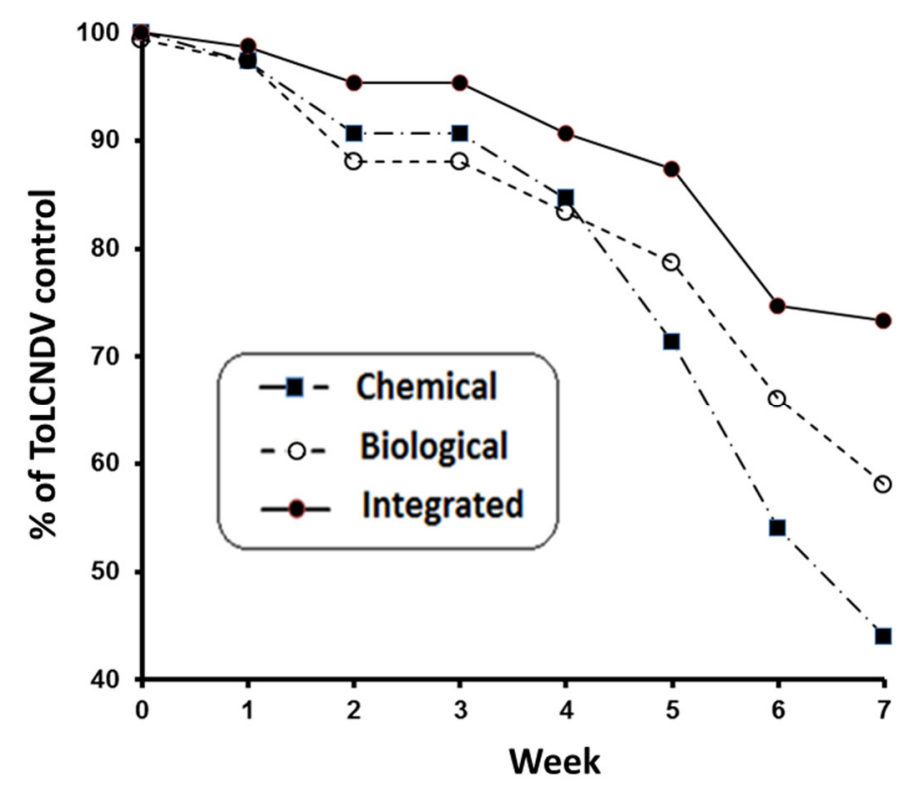

Figure 5. Control of ToLCNDV in zucchini under chemical, biological, and integrated management.

Table 5. Mean values of area under the disease progress curve (AUDPC) of ToLCNDV-symptomatic plants in experimental zucchini greenhouse compartments.

\begin{tabular}{ccccc}
\hline Difference AUDPC Means & M1-M2 & 95\% Confidence Interval (Wald) & $\boldsymbol{t}$-Difference & $\boldsymbol{p}$ Value \\
\hline Biological vs. Integrated & 3.36 & $1.02-7.77$ & 1.607 & $>0.0500$ \\
Chemical vs. Integrated & 5.06 & $0.57-9.54$ & 2.369 & 0.0292 \\
Chemical vs. Biological & 2.06 & $-2.34-6.41$ & 0.980 & $>0.0500$ \\
\hline
\end{tabular}

\section{Discussion}

Together with two-spotted spider mite (Tetranychus urticae Koch) (Acarina: Tetranychidae) and western flower thrips (Frankliniella occidentalis Pergande) (Thysanoptera, Thripidae), the whitefly B. tabaci constitutes the main pest of zucchini in the Mediterranean region [28]. Consequently, we found B. tabaci commonly infesting this crop species in greenhouses from SE Spain during the three consecutive years of study (Table 2). No silverleaf symptoms were observed, consistent with previous results that characterized the whitefly as cryptic species MedQ1 [5].

Of the complex of beneficial insects that are used for B. tabaci control in protected horticultural crops in SE Spain, the parasitoid E. mundus and the predator $N$. tenuis were found only in a few greenhouses during the period of monitoring (Table 2). Instead, A. swirskii was frequently observed especially during the first and the last year of monitoring. This natural enemy has been commercially 
available in Spain since 2007, and is increasingly used to control pests in pepper and recently also in cucumber crops [18]. However, biological control-based IPM in zucchini is applied on a very limited scale, i.e., only 1050 ha, which is $13.2 \%$ of the greenhouse area dedicated to zucchini. This is in contrast with solanaceous crops in Almería, where natural enemies are intensively applied in pepper $(100 \%$ of crops) and tomato (80\%) (crop season of 2016/2017) (Junta de Andalucía, Consejeria Agricultura y Pesca). Our results seem to confirm this trend: farmers did not rely on IPM for whitefly control in zucchini, and chemical treatments were progressively preferred during the campaigns between 2015 and 2018 (Table 3). Besides the emerging threat of ToLCNDV in zucchini, another reason explaining the limited application of biological control is that predatory mites lack the time for populations to increase on this short-cycle crop, and thus may fail to provide good biological control of pests. In this sense, the preventative installation of $A$. swirskii in young plants during the nursery period could help to overcome the problem of mite establishment in zucchini crops. This technique has proven to be very successful in semifield conditions [20].

Experimental data from the three treatments evaluated for whitefly control showed that those that involved the use of the predatory mite, i.e., biological and IPM treatments, resulted in better pest control (Table 4, Figure 4). The whitefly population growth fitted a logistic function fairly well in both cases. A. swirskii is an efficient predator of eggs and crawlers of $B$. tabaci $[14,29]$ and can suppress populations of the tobacco whitefly [30]. Previous results have shown that $B$. tabaci adults avoid plants with preinstalled $A$. swirskii (colonization) and therefore contributed to further control of $B$. tabaci populations (reproduction) [20]. Although both biological and IPM strategies were ultimately effective in suppressing the whiteflies, biological treatment resulted in a significantly better pest control when compared with IPM. This might be due to the higher pest pressure onto the IPM compartments during the experiment (Figure 3). On the other hand, the increase of the whitefly population on plants with the chemical treatment was described by an exponential growth equation, and no further decrease in the pest population could be observed during the experimental period (Figure 4). Our results are consistent with those from other studies where B. tabaci has been difficult to control with conventional insecticides in horticultural production systems [8,31]. In fact, B. tabaci is able to develop resistance to synthetic pesticides [32]. Moreover, the pesticide switching method used in this context (conventional management) will result in multiple pesticide resistance, and lead to negative effects on whitefly control. In the past, chemical pest control programs applied in horticulture greenhouses from Almería have proved totally unsustainable [33].

B. tabaci can transmit 12 viruses in countries of the West-Mediterranean, all of which have been described in Spain [34]. One of the recently introduced viruses is ToLCNDV, which infects solanaceous and cucurbitaceous crops, but is especially aggressive in zucchini. We found symptoms of ToLCNDV in all but one of the 35 monitored greenhouses. Since its introduction in 2013, this virus is the main disease in the region. Juarez et al. [11] detected ToLNDV in 182 of 191 collected zucchini samples in the neighboring Autonomous Community of Murcia during five consecutive cropping seasons (2012-2016). ToLCNDV symptoms are dependent on the cultivar and growing conditions, although common symptoms may include curling and yellowing in young leaves of zucchini plants, and vein swelling in cucumber plants [35].

The experimental comparison of the three different whitefly control strategies, showed that the chemical strategy was the least efficient in controlling the evolution of ToLCNDV in zucchini (Table 5, Figure 5). It has also been postulated that synthetic chemicals may affect the behavior of vectors, and hence of virus transmission [36]. Virus acquisition and transmission by insects often occurs too fast for insecticides to control viral dispersal. Pesticide treatment has been shown to be inefficient in controlling tospoviruses transmitted by thrips [37], and even enhances the dispersal of potyviruses transmitted by aphids [38]. This should be further studied in the case of whiteflies and the viruses they transmit.

Insect predators and parasitoids can be effective in controlling pests, and consequently putative vectors of viruses, in greenhouse crops [39]. However, they are considered unable to control transmission of viruses [40]. In the case of ToLCNDV in zucchini, A. swirskii does not prevent primary infections 
from invading viruliferous whiteflies, but this predator controls significantly secondary spread of the virus from infested and infected host plants [20]. The experimental comparison of control strategies in the present paper showed that the use of integrated whitefly management led to the best control of ToLCNDV dispersal (Figure 5, Table 5). Likely, pesticides used under the IPM strategy reduced the primary infection of zucchini plants without compromising the biological control of the secondary virus spread. Results suggest that insecticides were harmful to invading whitefly adults and therefore reduced the overall primary virus infection. Moreover, these insecticides that were effective against B. tabaci adults were relatively compatible with A. swirskii, which preys on eggs and crawlers of B. tabaci, resulting in a strong decrease of new viruliferous whiteflies and, consequently, a significant reduction of virus incidence. However, this study does not prove that $A$. swirskii can reduce virus incidence on a large commercial scale and under true greenhouse conditions. Future experiments should confirm this hypothesis. Note that only the simplest $B$. tabaci-A. swirskii system has been employed in the present work to address the key issue related to whitefly control and virus suppression. Under commercial greenhouse conditions, several variables may affect functional responses of the A. swirskii which have not been included in this experimental work, and which could significantly affect the outcome of whitefly control and virus spread. Some of these factors are a varying environment (temperature and humidity), presence of alternative prey, intraguild predation, cultural practices, and plant management practices (e.g., irrigation, fertilization, and disease control). All these variables cannot be completely evaluated under noncommercial conditions, even in experimental greenhouses. Thus, the results emphasize the need to adopt a biological control-based IPM which will reduce ToLCNDV incidence in commercial zucchini crops, whilst reducing the harms that accompany the use of chemicals, including those associated with environmental pollution, and the widespread resistance and resurgence of $B$. tabaci.

\section{Conclusions}

The use of chemical pesticides is the main strategy adopted by growers in commercial zucchini greenhouses from SE Spain to control Bemisia tabaci whiteflies; however ToLCNDV is widespread. Under experimental conditions, a biological control strategy involving the predatory mite Amblyseius swirskii in source plants decreased the whitefly abundance in zucchini crops. Biological control-based IPM was the best strategy for virus suppression. The exclusion of invading whitefly adults by using IPM-compatible pesticides reduced the primary spread of the whitefly-transmitted virus, whereas the predation of eggs and crawlers (first nymphal instar) by the mites reduced secondary virus spread. Finally, the maximum values of whitefly adults as well as of virus symptoms were found in crops under the conventional (chemical), strategy, suggesting that whitefly control by pesticides was the worst strategy for pest control and virus suppression. Therefore, the biological control-based IPM strategy proposed here might reduce the abuse of pesticides and efficiently address the virus risk that limits current commercial zucchini production in SE Spain.

Author Contributions: All authors designed and performed the experiments. All authors discussed the results and contributed to the final manuscript. E.R. and D.J. wrote the manuscript with input from M.M.T., D.J. worked out the field data and plant virus results. M.M.T. derived the models and analyzed the pest data.

Funding: This research was funded by project E-RTA2013-00020-C04-01 by the Spanish National Institute for Agricultural and Food Research and Technology (INIA) and FEDER. E. Rodríguez held a postdoctoral contract (DOC-INIA program) granted by Spanish National Institute for Agricultural and Food Research and Technology (INIA) and the European Social Fund.

Acknowledgments: The authors would like to thank Jose Antonio Valero Molina (Tragsa) and Rafael Sanchez Trujillo (Consejería de Agricultura, Ganadería, Pesca y Desarrollo Sostenible. Junta de Andalucía) for supplying the field data from RAIF. The authors are grateful to Prof Tomás Cabello (University of Almería) for his useful assistance with data analysis. We thank Marta Fernández for her technical assistance.

Conflicts of Interest: The authors declare no conflict of interest. The granting agencies have no role in study design, data collection, interpretation and analysis of data or decision to publish. 


\section{References}

1. Oliveira, M.R.V.; Henneberry, T.J.; Anderson, P. History, current status, and collaborative research projects for Bemisia tabaci. Crop Prot. 2001, 20, 709-723. [CrossRef]

2. Polston, J.E.; De Barro, P.; Boykin, L.M. Transmission specificities of plant viruses with the newly identified species of the Bemisia tabaci species complex. Pest Manag. Sci. 2014, 70, 1547-1552. [CrossRef] [PubMed]

3. Mansoor, S.; Briddon, R.W.; Zafar, Y.; Stanley, J. Geminivirus disease complexes: An emerging threat. Trends Plant Sci. 2006, 8, 128-134. [CrossRef]

4. Navas-Castillo, J.; Fiallo-Olivé, E.; Sánchez-Campos, S. Emerging Virus Diseases Transmitted by Whiteflies. Annu. Rev. Phytopathol. 2011, 49, 219-248. [CrossRef]

5. Janssen, D.; Simon, A.; Crespo, O.; Ruiz, L. Genetic population structure of Bemisia tabaci in Spain associated with Tomato leaf curl New Delhi virus. Plant Prot. Sci. 2017, 53, 25-31.

6. Guirao, P.; Beitia, F.; Cenis, J.L. Biotype determination of Spanish populations of Bemisia tabaci (Hemiptera: Aleyrodidae). Bull. Entomol. Res. 1997, 87, 587-593. [CrossRef]

7. Luo, C.; Jones, C.M.; Devine, G.; Zhang, F.; Denholm, I.; Gorman, K. Insecticide resistance in Bemisia tabaci biotype Q (Hemiptera: Aleyrodidae) from China. Crop. Prot. 2010, 29, 429-434. [CrossRef]

8. Yao, F.-L.; Zheng, Y.; Huang, X.-Y.; Ding, X.-L.; Zhao, J.-W.; Desneux, N.; He, Y.-X.; Weng, Q.-Y. Dynamics of Bemisia tabaci biotypes and insecticide resistance in Fujian province in China during 2005-2014. Sci. Rep. 2017, 7, 40803. [CrossRef] [PubMed]

9. Horowitz, A.R.; Ishaaya, I. Dynamics of biotypes B and Q of the whitefly Bemisia tabaci and its impact on insecticide resistance. Pest Manag. Sci. 2014, 70, 1568-1572. [CrossRef] [PubMed]

10. Fernández, E.; Grávalos, C.; Haro, J.P.; Cifuentes, D.; Bielza, P. Insecticide resistance status of Bemisia tabaci Q-biotype in south-eastern Spain. Pest Manag. Sci. 2009, 65, 885-891. [CrossRef]

11. Juarez, M.; Tovar, R.; Fiallo-Olivé, E.; Aranda, M.A.; Gosálvez, B.; Castillo, P.; Moriones, E.; Navas-Castillo, J. First detection of Tomato leaf curl new Delhi virus infecting zucchini in Spain. Plant Dis. 2014, 98, 857. [CrossRef] [PubMed]

12. Simon, A.; Ruiz, L.; Velasco, L.; Janssen, D. Absolute quantification of Tomato leaf curl New Delhi virus Spain strain, ToLCNDV-ES: Virus accumulation in a host-specific manner. Plant Dis. 2017, 102, 165-171. [CrossRef] [PubMed]

13. Annunziata, A.; Pascale, P. Consumers' Behaviours and Attitudes toward Healthy Food Products: The case of Organic and Functional foods. In Proceedings of the 113th EAAE Seminar A Resilient European Food Industry and Food Chain in A Challenging World, Chania, Greece, 3-6 September 2009.

14. Nomikou, M.; Janssen, A.; Schraag, R.; Sabelis, M.W. Phytoseiid predators as potential biological control agents for Bemisia tabaci. Exp. Appl. Acarol. 2001, 25, 271-291. [CrossRef]

15. Calvo, F.J.; Bolckmans, K.; Belda, J. Controlling the tobacco Whitefly Bemisia tabaci (Genn.) (Hom.: Aleyrodidae) in horticultural crops with the predatory mite Amblyseius swirskii (Athias-Henriot). J. Insect Sci. 2008, 8, 11-12.

16. Calvo, F.J.; Bolckmans, K.; Belda, J.E. Control of Bemisia tabaci and Frankliniella occidentalis in cucumber by Amblyseius swirskii. Biocontrol 2011, 56, 185-192. [CrossRef]

17. Calvo, F.J.; Bolckmans, K.; Belda, J.E. Biological control-based IPM in sweet pepper greenhouses using Amblyseius swirskii (Acari: Phytoseiidae). Biocontrol Sci. Technol. 2012, 22, 1398-1416. [CrossRef]

18. Calvo, F.J.; Knapp, M.; van Houten, Y.M.; Hoogerbrugge, H.; Belda, J.E. Amblyseius swirskii: What made this predatory mite such a successful biocontrol agent? Exp. Appl. Acarol. 2014, 65, 419-433. [CrossRef]

19. Téllez, M.M. Estrategia de control biológico mediante la utilización de Amblyseius swirskii Athias-Henriot en cultivo de pepino. Phytoma 2015, 272, 20-24.

20. Téllez, M.M.; Simon, A.; Rodriguez, E.; Janssen, D. Control of tomato leaf curl New Delhi virus in zucchini using the predatory mite Amblyseius swirskii. Biol. Control 2017, 114, 106-113. [CrossRef]

21. Ruiz, L.; Simon, A.; Velasco, L.; Janssen, D. Biological characterization of Tomato leaf curl New Delhi virus from Spain. Plant Pathol. 2017, 66, 376-382. [CrossRef]

22. Junta de Andalucía 2019. Available online: http://www.juntadeandalucia.es/agriculturaypesca/raif (accessed on 1 February 2019). 
23. Gueguen, G.; Vavre, F.; Gnankine, O.; Peterschmitt, M.; Charif, D.; Chiel, E.; Gottlieb, Y.; Ghanim, M.; Zchori-Fein, E.; Fleury, F. Endosymbiont metacommunities, mtDNA diversity and the evolution of the Bemisia tabaci (Hemiptera: Aleyrodidae) species complex. Mol. Ecol. 2010, 19, 4365-4376. [CrossRef] [PubMed]

24. Ruppel, R.F. Cumulative insect-days as an index of crop protection. J. Econ. Entomol. 1983, 76, 375-377. [CrossRef]

25. IBM Corp. Released 2017. IBM SPSS Statistics for Windows; Version 25.0; IBM Corp.: Armonk, NY, USA, 2017.

26. Therneau, T.; Grambsch, P.M. Modeling Survival Data-Extending the Cox Model; Springer: New York, NY, USA, 2000.

27. Campbell, C.L.; Madden, L.V. Introduction to Plant Disease Epidemiology; John Wiley \& Sons: New York, NY, USA, 1990.

28. Tello, J.C.; Camacho, F. Organisms for the Control of Pathogens in Protected Crops. Cultural Practices for Sustainable Agriculture; Fundación Cajamar: Almería, Spain, 2014.

29. Nomikou, M.; Janssen, A.; Schraag, R.; Sabelis, M.W. Vulnerability of Bemisia tabaci immatures to phytoseiid predators: Consequences for oviposition and influence of alternative food. Entomol. Exp. Appl. 2004, 110, 95-102. [CrossRef]

30. Messelink, G.J.; van Maanen, R.; van Steenpaal, S.E.F.; Janssen, A. Biological control of thrips and whiteflies by a shared predator: Two pests are better than one. Biol. Control 2008, 44, 372-379. [CrossRef]

31. Palumbo, J.C.; Horowitz, A.R.; Prabhaker, N. Insecticidal control and resistance management for Bemisia tabaci. Crop Prot. 2001, 20, 739-765. [CrossRef]

32. Grávalos, C.; Fernández, E.; Belando, A.; Moreno, I.; Ros, C.; Bielza, P. Cross-resistance and baseline susceptibility of Mediterranean strains of Bemisia tabaci to cyantraniliprole. Pest Manag. Sci. 2015, 71, 1030-1036. [CrossRef] [PubMed]

33. Van der Blom, J. Applied entomology in Spanish greenhouse horticulture. Proc. Neth. Entomol. Soc. Meet. 2010, 21, 9-17.

34. Janssen, D.; Ruiz, L.; Garcia, C. Viruses transmitted by the whitefly Bemisia tabaci in organic greenhouse crops: Current situation and risks in Europe. BioGreenhouse 2017. [CrossRef]

35. Juárez, M.; Rabadán, M.P.; Martínez, L.D.; Tayahi, M.; Grande-Pérez, A.; Gómez, P. Natural hosts and genetic diversity of the emerging tomato leaf curl New Delhi virus in Spain. Front. Microbiol. 2019, 10, 140. [CrossRef]

36. Perring, T.M.; Gruenhagen, N.M.; Farrar, C.A. Management of plant viral diseases through chemical control of insect vectors. Annu. Rev. Entomol. 1999, 44, 457-481. [CrossRef]

37. Pappu, H.R.; Jones, R.A.; Jain, R.K. Global status of tospovirus epidemics in diverse cropping systems: Successes achieved and challenges ahead. Virus Res. 2009, 141, 219-236. [CrossRef] [PubMed]

38. Thieme, T.; Hoffmann, U.; Heimbach, U. Efficacy of plant protection substances against virus transmission by aphids infesting potato. J. Kult. 2009, 61, 21-30.

39. Pilkington, L.J.; Messelink, G.; van Lenteren, J.C.; Le Mottee, K. Protected Biological Control-Biological pest management in the greenhouse industry. Biol. Control 2010, 52, 216-220. [CrossRef]

40. Bragard, C.; Caciagli, P.; Lemaire, O.; López-Moya, J.J.; MacFarlane, S.; Peters, D.; Susi, P.; Torrance, L. Status and prospects of plant virus control through interference with vector transmission. Annu. Rev. Phytopathol. 2013, 51, 177-201. [CrossRef]

(C) 2019 by the authors. Licensee MDPI, Basel, Switzerland. This article is an open access article distributed under the terms and conditions of the Creative Commons Attribution (CC BY) license (http://creativecommons.org/licenses/by/4.0/). 